\title{
PERSIAPAN IBU NIFAS SELAMA MENYUSUI DI MASA ADAPTASI KEBIASAAN BARU DALAM PEMBERIAN ASI
}

\author{
${ }^{1)}$ Setiana Andarwulan", ${ }^{2)}$ Indria Nuraini \\ ${ }^{1)}$ Program Studi D III Kebidanan, Fakultas Sains Kesehatan, Universitas PGRI Adi Buana Surabaya \\ ${ }^{2)}$ Program Studi D III Kebidanan, Fakultas Sains Kesehatan, Universitas PGRI Adi Buana Surabaya \\ *Alamat: Jln Dukuh Menanggal XII no 4 -8 Gayungan Surabaya \\ *Email: setianaandarwulan@unipasby.co.id
}

\begin{abstract}
ABSTRAK
ASI merupakan makanan pokok bayi. Ibu nifas memberikan ASI kepada bayinya selama 6 bulan. Pemberian ASI oleh ibu yang dilakukan selama masa adaptasi kebiasaan baru, masih saja diikuti dengan isu - isu yang berisi tentang larangan pemberian ASI, bila ibu yang melahirkan mengalami positif covid -19. Kegiatan PPM (Pengabdian Pada Masyarakat) dengan tema "Peran Keluarga Dalam Meningkatkan Kesehatan Ibu dan Anak Di Masa Adaptasi Kebiasaan Baru dengan sub tema "Persiapan Ibu Nifas Selama Menyusui Di Masa Adaptasi Kebiasaan Baru Dalam Pemberian ASI " bertujuan untuk meningkatkan pengetahuan dan ketrampilan ibu nifas melalui peran keluarga, ketika beradaptasi dengan kebiasaan baru setelah periode adaptasi new normal. Selain itu kegiatan ini sebagai upaya dalam meningkatkan pengetahuan ibu nifas supaya tetap sehat di era adaptasi kebiasaan baru. Peran keluarga menjadi hal yang sangat penting demi keberlangsungan hidup selama proses adaptasi berlangsung. Seorang ibu nifas akan memulai hal baru dengan melakukan adaptasi dengan kebiasaan baru. Adaptasi ini membutuhan pengetahuan dan pemahaman yang betul sebagai bekal supaya menyusui selama adaptasi kebiasaan baru dapat tercapai. Webinar tentang mitos kebiasaan baru menyusui dapat membantu para ibu yang sedang memiliki pemahaman yang kurang tentang adanya adaptasi kebiasaan baru selama menyusui. Selain itu dengan adanya dukungan keluarga juga dapat membantu keberhasilan menyusui. Dengan demikian peran keluarga dalam meningkatkan kesehatan ibu nifas selama beradaptasi dengan kebiasaan baru dapat tercapai.
\end{abstract}

Kata Kunci : Ibu, Nifas, Menyusui

\begin{abstract}
Breast milk is the staple food for babies. Postpartum mothers provide breast milk to their babies for 6 months. Breastfeeding by mothers during the adaptation period for new habits is still followed by issues that contain the prohibition of breastfeeding, if the mother who gives birth is positive for Covid -19. The PPM (Community Service) activity with the theme "The Role of Families in Improving Maternal and Child Health in the Adaptation Period for New Habits with the sub-theme" Preparing for Postpartum Mother During Breastfeeding in the Adaptation Period for New Habits in Breastfeeding "aims to increase the knowledge and skills of postpartum mothers through family role, when adapting to new habits after a new normal adaptation period. In addition, this activity is an effort to increase the knowledge of postpartum mothers so that they stay healthy in the era of adapting to new habits. The role of the family is very important for survival during the adaptation process. A postpartum mother will start new things by adapting to new habits. This adaptation requires proper knowledge and understanding as provisions so that breastfeeding during the adaptation of new habits can be achieved. Webinars on the myths of new breastfeeding habits can help mothers who have a poor understanding of adapting to new habits during breastfeeding. In addition, family support can also help breastfeeding success. Thus the role of the family in improving the health of postpartum mothers while adapting to new habits can be achieved.
\end{abstract}

Keywords: mother, childbirth, breastfeeding 
Volume. 1 No. 2 tahun 2020 Nov 2020 - Mei 2021
ISSN (online): 2722-2055 https://jurnal.umj.ac.id/index.php/ASSYIFA
AS-SYIFA: Jurnal Pengabdian dan Pemberdayaan Kesehatan Masyarakat

\section{PENDAHULUAN}

Coronavirus adalah patogen penting yang umum terjadi pada manusia dan hewan. Pada Desember 2019, sebuah novel coronavirus (2019 novel coronavirus, 2019-nCoV) ditemukan di Wuhan, Provinsi Hubei, China, yang menyebabkan penyebaran cepat kasus pneumonia di Wuhan dan daerah sekitarnya di China. Selanjutnya, ada lebih banyak kasus di negara lain di dunia. Pada Februari 2020, Organisasi Kesehatan Dunia menobatkan 2019 Coronavirus Disease 2019 (COVID-19). (Wu et al., 2020) ((Rosen et al., 2020). Coronavirus Disease ( COVID-19) merupakan penyakit jenis baru yang muncul dan menyerang pada manusia. Sebelumnya ada dua jenis penyakit baru yang menyebabkan gejala berat yaitu SARS ( Severe Acute Respiratory Syndrome ) dan MERS ( Middle East Respiratory Syndrome ). Penelitian menyebutkan SARS ditularkan melalui kucing luwak sedangkan MERS dari unta ke manusia. ( Kemenkes, 2020 ).

Menurut ( Survey Demografi Kesehatan Indonesia ) SDKI sebelum adanya COVID19 masalah tentang kesehatan Ibu dan Anak yaitu angka kematian ibu mencapai 305/100.000 kelahiran hidup pada tahun 2015, pada bayi baru lahir nilai kematian mencapai 15/ 1000 kelahiran hidup pada tahun 2017, angka yang tidak ber KB mencapai 11 orang/ 100 pada tahun 2017, prevalensi stunting mencapai 30,8 \% pada tahun 2018, dan kasus gizi buruk mencapai 5,7 \% pada tahun 2013. ( SDKI, 2017 ). Sedangkan data otentik dari satgas covid pada tanggal 12 Juli 2020, menyebutkan bahwa angka kejadian terkonfirmasi covid secara global mencapai 17.660.523 orang sedangkan di Indonesia mencapai 135.123 orang. Data untuk ibu hamil yang terkonfirmasi positif sebanyak 4,9\% dari 1389 ibu hamil.. Selain itu juga disebutkan tentang ibu hamil yang mengalami perawatan di Indonesia selama pandemic COVID-19, yaitu 24 orang di RSUP Jakarta. Data untuk kematian pada ibu hamil sendiri belum terekspos secara keseluruhan. Data terakhir yang di dapat adalah seorang ibu hamil dengan kehamilan 4 bulan meninggal di RSAL Surabaya. ( Data Satgas Covid, 2020 ).

Masa nifas pada ibu setelah melahirkan selama 40 hari ( Setiana, 2019 ). Setelah bayi lahir untu dilakukan inisiasi menyusui dini, Inisiasi menyusui dini bermanfaat bagi setiap bayi yang baru lahir - di mana pun mereka tinggal. ( UNICEF, 2018 ). Menyusui adalah landasan utama kelangsungan hidup bayi dan anak kecil, gizi dan perkembangan serta kesehatan ibu. Organisasi Kesehatan Dunia merekomendasikan pemberian ASI eksklusif selama 6 bulan pertama kehidupan, diikuti dengan pemberian ASI berkelanjutan dengan makanan pendamping yang sesuai hingga 2 tahun ke atas. Kontak kulit-ke-kulit 
secara dini dan tidak terputus, rawat gabung-in dan perawatan ibu kanguru juga meningkat secara signifikan kelangsungan hidup neonatal dan menurunkan morbiditas dan direkomendasikan oleh WHO. Namun, kekhawatiran telah muncul tentang apakah ibu dengan COVID-19 dapat menularkan virus SARS-CoV-2 ke bayi atau anak kecil mereka melalui menyusui. ( WHO, 2020 )

Rekomendasi kontak ibu-bayi dan menyusui harus didasarkan pada pertimbangan penuh tidak hanya pada potensi risiko infeksi COVID-19 pada bayi, tetapi juga risiko morbiditas dan mortalitas yang terkait dengan tidak menyusui, penggunaan formula bayi yang tidak tepat. susu, serta efek perlindungan dari kontak kulit-ke-kulit. COVID-19 harus didorong untuk mulai atau terus menyusui. Para ibu harus diberi tahu bahwa manfaat menyusui secara substansial lebih besar daripada potensi risiko penularan. Ibu dan bayi harus dimungkinkan untuk tetap bersama selama rawat inap sepanjang hari dan malam dan untuk mempraktikkan kontak kulit-ke-kulit, termasuk perawatan ibu kanguru, terutama segera setelah lahir dan selama menyusui, apakah mereka atau bayinya telah mencurigai atau mengonfirmasi COVID-19. ( WHO, 2020 ).

Berdasarkan bukti ilmiah COVID-19 dapat menular dari manusia ke manusia melalui percikan batuk dan bersin, tidak melalui udara. Orang yang paling beresiko tertular penyakit ini adalah orang yang kontak erat dengan pasien COVID-19 termasuk merawat pasien. Rekomendasi standart untuk mencegah penyebaran infeksi adalah melalui cuci tangan, menghindari kontak secara langsung dengan ternak dan binatang liar serta menghindari kontak dekat dengan siapapun yang menunjukkkan gejala penyakit pernapasan seperti batuk dan bersin. Selain itu, menerapkan pencegahan dan pengendalian infeksi saat berada di fasilitas kesehatan terutama unit gawat darurat ( Kemenkes, 2020 ) (Zukmadani, Karyadi and Kasrina, 2020).

Tujuan Pengabdian Kepada Masyarakat yang diselenggarakan melalui webinar pengabdian kepada masyarakat dengan sub tema Persiapan Ibu Nifas Selama Menyusui Di Masa Adaptasi Kebiasaan Baru Dalam Pemberian ASI, adalah memberikan pengetahuan dalam pelayanan kebidanan terutama kepada ibu nifas dalam memberikan ASI kepada bayinya di masa adaptasi kebiasaan baru. Selain itu memberikan informasi tentang cara pemberian ASI selama masa pandemi, sehingga ibu nifas dalam memberikan ASI menggunakan protokol kesehatan yaitu dengan memakai masker, mencuci tangan, dan memakai handsanitaizer. ((Larasati, Gozali and Haribowo, 2020) 
Volume. 1 No. 2 tahun 2020

Nov 2020 - Mei 2021
ISSN (online): 2722-2055 https://jurnal.umj.ac.id/index.php/ASSYIFA
AS-SYIFA: Jurnal Pengabdian dan

Pemberdayaan Kesehatan

Masyarakat

\section{METODE}

Metode yang dilaksanakan pada Pelaksanaan Pengabdian Masyarakat melalui webinar dibagi menjadi :

a. Pembagian fliyer tentang jadwal pelaksaan PPM

b. Penbentukan grup via WA yang menjadi peserta PPM

c. Penyelenggaraan dan pelaksanaan PPM melalui webinar

d. Pengisian absensi dan evaluasi PPM

Adapun konsep yang diterapkan pada kegiatan ini melalui pendekatan berbasis komunitas, dimana strategi untuk meningkatkan pengetahuan, kemauan, dan kesadaran para ibu dan keluarga dalam beradaptasi dengan kebiasaan baru.

Pada tahap pertama tim dosen sebagai penyelenggara melakukan pembagian fliyer untuk para peserta melaui media massa. Langkah ini diambil sebagai salah satu cara untuk menjaring peserta dalam mengikuti kegiatan webinar nantinya. Selanjutnya peserta dapat melakukan registrasi pada link yang terdapat dalam fliyer tersebut dalam bentuk gform.

Pada tahap kedua langkah yang diambil adalah membentuk grup WA. Di dalam grup tersebut peserta dikumpulkan dalam satu kelompok webinar. Melalui layanan WA grup ini peserta dapat mengajukan pertanyaan bila ada yang ingin ditanyakan sebelum pelaksanaan webinar berlangsung bila ada yang kurang jelas.

Pada tahap ketiga masuk ke acara inti yaitu penyelenggaraan dan pelaksanaan program pengabdian kepada masyarakat melalui webinar. Di dalam webinar tersebut terdapat 5 pembicara, yang akan mengupas tuntas tentang materi - materi yang berhubungan dengan peran keluarga dalam meningkatkan kesehatan ibu dan anak di masa adaptasi kebiasaan baru. Materi yang disampaikan meliputi : kehamilan, persalinan, nifas, bayi dan anak, serta KB dan kespro.

Diakhir sesi dilakukan evaluasi dengan membagikan kuesioner, data kuesioner yang diolah mengenai pengetahuan ibu nifas setelah diberikan informasi tentang pemberian ASI di masa adtasi baru. Melalui pengetahuan ibu nifas yang baik akan meningkatkan dalam pemberian ASI meski selama berlangsung masa adaptasi kebiasaan baru. Pelaksanaan kegiatan webinar sebagai bentuk pengabdian kepada masyarakat. Dengan demikian dapat menjadi acuan bagi penyelenggara bila ada hal - hal yang menghambat penyelenggaran sehingga sebagai bahan koreksi dalam peningkatan penyelenggaraan selanjutnya. 
Volume. 1 No. 2 tahun 2020 Nov 2020 - Mei 2021
AS-SYIFA: Jurnal Pengabdian dan Pemberdayaan Kesehatan Masyarakat

\section{HASIL DAN PEMBAHASAN}

Tim pengabdian kepada masyarakat melaksanakan kegiatan ini pada tanggal 15 Agustus 2020. Kegiatan pengabdian kepada masyarakat melibatkan peserta webinar secara online. Webinar pengabdian kepada masyarakat ini berlokasi di Fakultas Sains Kesehatan Universitas PGRI Adi Buana Surabaya. Jumlah peserta yang mengikuti webinar pengabdian kepada masyarakat melalui registrasi link sebanyak 1500 peserta. Peserta terdiri dari masyarakat, tenaga kesehatan dan profesi lainnya. Webinar ini bertujuan untuk meningkatkan pengetahuan dan ketrampilan khususnya pada ibu nifas melalui pemanfaatan zoom. Sehingga ibu nifas mampu dalam menghadapi masa adaptasi kebiasaan baru. Ibu nifas memberikan dan menerapkan pengetahuan selama pemberian ASI di masa adaptasi kebiasaan baru. Narasumber yang memberikan materi selama pelaksanaan webinar juga merapkan protokol kesehatan. Tempat duduk narasumber diatur sesuai dengan protokol kesehatan. Pada akhir kegiatan pelatihan peserta mendapatkan, antara lain; 1) Meningkatnya pengetahuan tentang pemberian ASI di masa adaptasi kebiasaan baru. 2) Memahami tentang tata cara pemberian ASI dengan menerapkan protokol kesehatan.

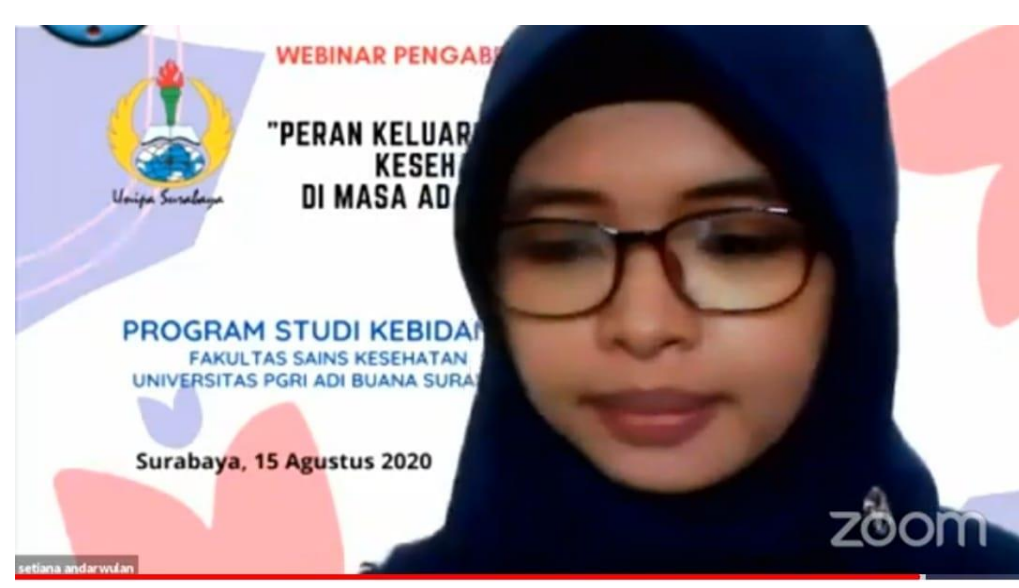

\section{Webinar Pengabdian kepada Masyarakat Program Studi Kebidanan ...}

$2 \mathrm{rb} \times$ ditonton
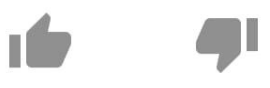

2

Bagikan

Download

Simpan 
ISSN (online): 2722-2055 https://jurnal.umj.ac.id/index.php/ASSYIFA
AS-SYIFA: Jurnal Pengabdian dan

Pemberdayaan Kesehatan Masyarakat

Gambar 1. Pemateri 3 mempresentasikan materinya

\section{DT Diva Tresna Anggraini}

\%. Dwi Rieswinda

Dwina Suprobo Kebidan...

\section{ER Eka rahmawati}

7 elly anggreini

F Febiana Ferlia S1 kebid...

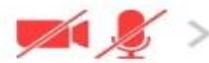

PID febryantri dyah wahyuni...

Gambar 2. Link pendaftaran peserta webinar

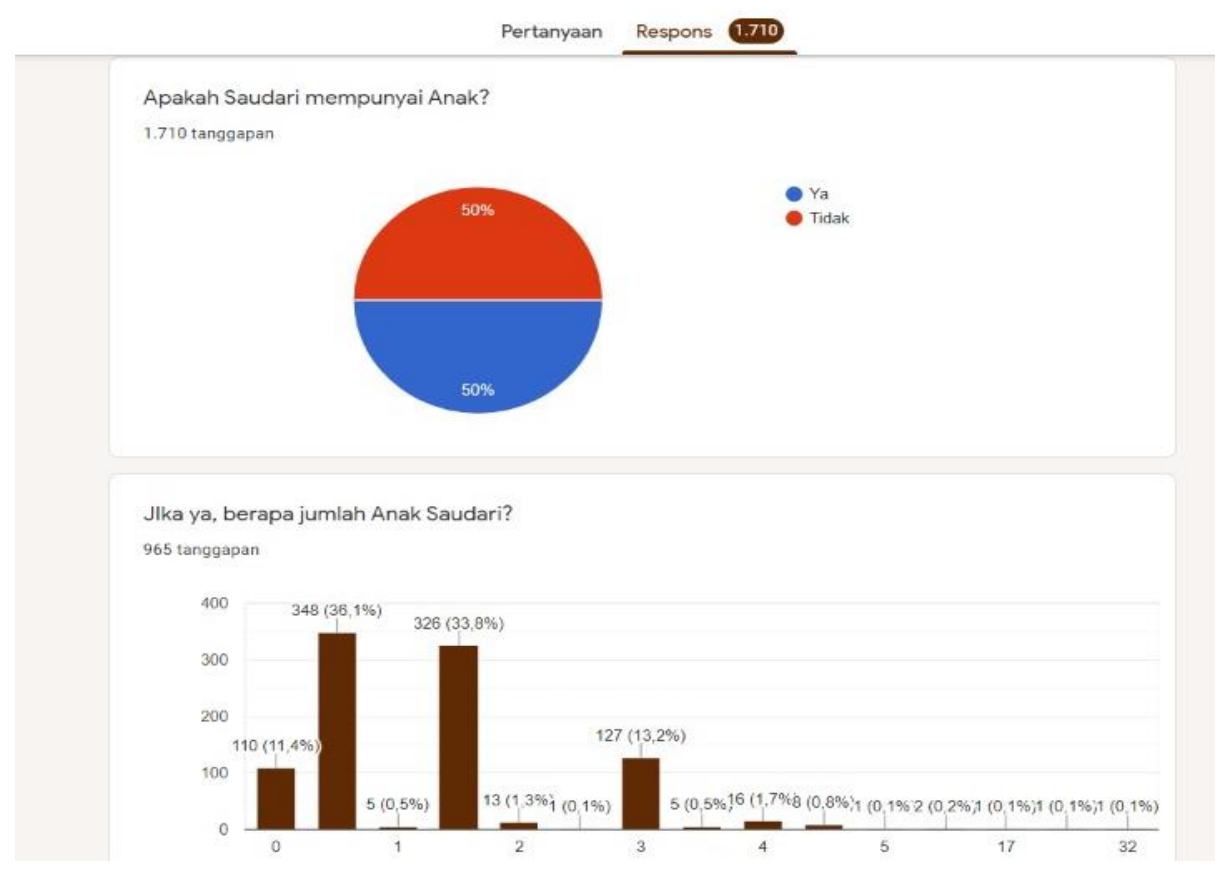

Gambar 3. Perserta yang mengikuti webinar melalui zoom 
AS-SYIFA: Jurnal Pengabdian dan Pemberdayaan Kesehatan Masyarakat

\section{KESIMPULAN DAN SARAN}

\section{KESIMPULAN}

a. Kegiatan webinar tentang adaptasi kebiasaan baru ibu nifas dapat meningkatkan pengetahuan ibu - ibu posyandu dalam melakukan adaptasi kebiasaan baru

b. Kegiatan webinar tentang adaptasi kebiasaan baru di masa nifas dapat meningkatkan ketrampilan ibu nifas dalam memberikan ASI kepada bayinya dengan penerapan protokol kesehatan.

\section{SARAN}

a. Perlu adanya keberlanjutan dalam penyelenggaraan webinar di masa nifas dengan adaptasi kebiasaan baru

b. Perlu adanya pengembangkan terhadap update ilmu - ilmu terbaru tentang info - info seputar covid-19 yang masih perlu banyak untuk disosialisasikan.

c. Perlu adanya peningkatan frekuensi penyelenggaraan yang dilaksanakan oleh para narasumber sehingga mampu membantu memberikan pemahaman kepada masyarakat tentang pentingnya beradaptasi di era pandemic.

\section{UCAPAN TERIMA KASIH}

Ucapan terimakasih disampaikan kepada bapak Agung Pramudjiono selaku kepala LPPM Universitas PGRI Adi Buana Surabaya. Dan semua pihak yang telah mendukaung dan mengikuti jalanya acara webinar. Terimakasih atas apresiasi dan dukungannya.

\section{DAFTAR PUSTAKA}

Academy of Breastfeeding Medicine. ABM Statement on Coronavirus 2019 (COVID-19). https://www.bfmed.org/abm-statementcoronavirus

https://www.who.int/reproductivehealth/publications/emergencies/Pregnancy-61200x1200.png?ua=1

CDC. Interim Guidance on Breastfeeding for a Mother Confirmed or Under Investigation For COVID-19.

http://www.elactancia.org/media/papers/Interim_Guidance_on_Breastfeeding_for_a_Mother COVID-19-CDC-2020.pdf

Larasati, A. L., Gozali, D. and Haribowo, C. (2020) 'Penggunaan Desinfektan dan Antiseptik Pada Pencegahan Penularan Covid-19 di Masyarakat', Majalah Farmasetika. doi: 10.24198/mfarmasetika.v5i3.27066.

Panduan menyusui dalam situasi pandemi COVID-19 oleh Kementerian Pemberdayaan Perempuan dan Perlindungan Anak Republik Indonesia.

https://covid19.go.id/edukasi/ibu-dan-anak/panduan-menyusui-dalam-situasi-pandemi-covid$\underline{19}$ 
Volume. 1 No. 2 tahun 2020 Nov 2020 - Mei 2021
ISSN (online): 2722-2055 https://jurnal.umj.ac.id/index.php/ASSYIFA
AS-SYIFA: Jurnal Pengabdian dan

Pemberdayaan Kesehatan Masyarakat

\section{www.woridometers.info/coronavirus/}

Pedoman Bagi Ibu Hamil, Bersalin, Nifas, Dan Bayi Baru Lahir di Era Pandemi COVID-19

$\begin{array}{lllll}\text { Revisi } & 1 . & \text { Kementerian } & \text { Kesehatan }\end{array}$ www.Pedoman_bagi_ibu_hamil_ibu_nifas_dan_BBL_selama_social_distancing.

Setiana, A. 2019. Asuhan Kebidanan Pada Ibu Nifas. Jakarta : Guepedia.

UNICEF. Statement from UNICEF Indonesia on Coronavirus (COVID-19) : Protect yourself by getting accurate information. https://www.unicef.org/indonesia/coronavirus

WHO. Q\&A on COVID-19, pregnancy, childbirth and breastfeeding. https://www.who.int/news-room/g-a-detail/g-a-on-covid-19pregnancy-childbirth-and-

breastfeeding

Rosen, M. H. et al. (2020) 'Management of Acute Severe Ulcerative Colitis in a Pregnant Woman With COVID-19 Infection: A Case Report and Review of the Literature', Inflammatory bowel diseases, 26(7). doi: 10.1093/ibd/izaa109.

Wu, Y. et al. (2020) 'Coronavirus disease 2019 among pregnant Chinese women: case series data on the safety of vaginal birth and breastfeeding', BJOG: An International Journal of Obstetrics and Gynaecology, 127(9). doi: 10.1111/1471-0528.16276.

Zukmadani, A. Y., Karyadi, B. and Kasrina (2020) 'Edukasi Perilaku Hidup Bersih dan Sehat (PHBS) dalam Pencegahan COVID-19 Kepada Anak-Anak di Panti Asuhan', Jurnal Pengabdian Masyarakat. 